\title{
Activity of $\beta$-lactam antibiotics against certain microorganisms which cause mastitis in cows
}

\author{
Artur Burmańczuk ${ }^{1}$, Cezary Kowalski ${ }^{1}$, Zbigniew Roliński ${ }^{1}$, \\ Rafał Zań ${ }^{1}$, Dorota Krasucka ${ }^{2}$ \\ ${ }^{1}$ Sub-Department of Pharmacology, Department of Preclinical Veterinary Sciences, Faculty of Veterinary Medicine, \\ University of Life Sciences in Lublin, 20-033 Lublin, Poland \\ ${ }^{2}$ Department of Veterinary Pharmacy, \\ National Veterinary Research Institute, 24-100 Pulawy, Poland \\ artur.burmanczuk@up.lublin.pl
}

Received: January 28, 2016 Accepted: July 22, 2016

\begin{abstract}
Introduction: The objective of this study was to determine the current profile of bacteria responsible for the infection of the mammary gland and to assess their sensitivity to selected $\beta$-lactam antibiotics. Material and Methods: The study was conducted on $119(\mathrm{n}=119)$ dairy cows of the Polish Black-White breed aged 4 to 10 years with inflammation of the mammary gland. The cows came from different farms: smallholder farms and large dairy cattle farms in the Lublin and Bialystok Provinces. Before the process of collection of milk samples, the teats were cleaned and immersed in a liquid disinfectant. The first streams were collected into containers which were subsequently utilised. Afterwards, $2-4 \mathrm{~mL}$ of milk or secretions was milked into sterile disposable tubes. The milk samples were collected into plastic bottles and kept in a cooler with ice until transportation to the laboratory. Tests of resistance to $\beta$-lactam antibiotics were performed by disc diffusion. Results: Contagious and environmental bacteria were isolated from all dairy barns. In the group of contagious bacteria, the presence of typical pathogens responsible for the mammary gland infections, i.e. Staph. aureus, Str. agalactiae, and C. bovis, was detected. A relatively broad group of the isolates was formed by environmental bacteria responsible for inflammation of the mammary gland: Str. dysgalactiae, Str. uberis, Staph. chromogenes, Staph. hyicus, Staph. warneri, and E. coli. Among the environmental organisms, streptococci constituted the largest percentage (23\%), followed by staphylococci (13.2\%), and E. coli ( $8.8 \%)$. The largest group of infectious pathogens comprised Str. agalactiae (29.6\%) and Staph. aureus (20.8\%). Conclusion: Our investigation of the current profile of the isolates responsible for mastitis in the Lublin and Bialystok Provinces showed that environmental bacteria are the major cause of the disease. In view of the substantially varying degrees of sensitivity of the microorganisms isolated from cases of mastitis to $\beta$-lactam antibiotics, each therapeutic treatment should be preceded by susceptibility testing.
\end{abstract}

Keywords: cow, mastitis, microorganisms, $\beta$-lactam antibiotics.

\section{Introduction}

The bacteria which cause mastitis in cows are classified as contagious or environmental pathogens depending on epidemiological link with the disease (20). Infectious pathogens, e.g. Staph. aureus and Str. agalactiae, as well as the less common C. bovis and $M$. bovis, have an ability to survive in the mammary gland. Their presence may lead to inflammation, which is usually manifested as an increase in the number of somatic cells in milk from infected quarters (1). Environmental pathogens causing the mammary gland infection occur in the immediate cow's environment, e.g. in litter, manure, and soil. This group includes streptococci, such as Str. dysgalactiae, Str. uberis, Enterococcus spp., E. coli, Klebsiella, and Enterobacter (18). In addition to bacteria, pathogenic environment includes fungi and algae (2). Inflammation of the mammary gland in cows is an important sanitary-epidemiological and economical issue $(4,15)$. The utility value of a cow is based on milk yield and its variations, which are determined by a series of factors that decide about an intensive or extensive breeding system. A principle in the treatment 
of mastitis is introduction of therapeutic agents into the mammary gland quarters devoid of inflammatory secretions, if not accompanied by inflammation of the overall reaction system. Antibiotics should only be used where justified and any abuse may cause unintended reactions, regardless of the general contraindications for their introduction to the environment (4, 11-14, 23-25).

The effectiveness of treatment depends on the aetiological factors causing the disease, but also the clinical symptoms, sensitivity of the microorganism to antibiotics, and efficiency of the immune system. Overuse or inappropriate use of antibiotics can lead to the development of resistance in different bacterial strains (19). In recent years, there has been a growing need to reduce the use of antibiotics in the treatment and prevention of diseases of animals (23). Therefore, to increase the effectiveness of the treatment, it is important to identify the strain and determine its sensitivity to antibiotics $(4,11,12,14,23,24)$.

The aim of this study was to determine the current profile of bacteria responsible for the infection of the mammary gland in cows and to assess their sensitivity to selected $\beta$-lactam antibiotics.

\section{Material and Methods}

The study was conducted on 119 dairy cows of the Polish Black-White breed aged 4 to 10 years with inflammation of the mammary gland and weighing about $650 \mathrm{~kg}$ each. The animals were fed farming feed concentrates comprising wheat, rye, and fodder grain (oats, barley), alternating with raw corn and pasture grazing. Access to food and water was provided ad libitum. The analyses were carried out between March and September. Cows were qualified for the research on guidance from the owners. The animals were verified using the DRAMINSKI Mastitis Detector $4 \times 4 \mathrm{Q}$ (Dramiński ${ }^{\circledR}$, Poland), a 4-quarter device for detecting subclinical mastitis in its earliest, visually undetectable stage, in order to assess the somatic cell count. Cows with a somatic cell count $\geq 400000 / \mathrm{mL}$ were classified for the study. The cows came from different farms (Table 2): smallholder farms with under 20 heads $(1,4,6,7,8$, and 12) and large dairy cattle farms holding over 50 animals $(2,3,5,9,10$, and 11) in the Lublin and Bialystok Provinces. Before the collection of milk samples, the teats were cleaned and immersed in a liquid disinfectant - Avitaderm (Agrovet - Sniadowo, Poland). Afterwards, their mouths were wiped with a swab soaked in $70 \%$ ethanol. The first streams were collected into containers which were subsequently utilised. Afterwards, 2-4 mL of milk or secretions was milked into sterile disposable tubes. The milk samples were collected into plastic bottles and kept in a cooler with ice until transportation to the laboratory. Tests of resistance to $\beta$-lactam antibiotics were performed by disc diffusion on Mueller-Hinton media, in accordance with NCCLS guidelines (NCCLS, 1987:199). The following Oxoid ${ }^{\mathrm{TM}}$ rings were used: penicillin $\mathrm{G}(10 \mathrm{IU})$, amoxicillin $(10 \mathrm{mg})$, ampicillin $(10 \mathrm{mg})$, cefoperazone $(30 \mathrm{mg})$, cefacetrile $(30 \mathrm{mg})$, cloxacillin $(5 \mu \mathrm{g})$, cefalexin $(30 \mathrm{mg})$, cefazolin $(30 \mathrm{mg})$, and cefalothin $(30 \mu \mathrm{g})$. Staph. aureus ATCC25 923 and E.coli ATCC25 922 were used as reference strains. Evaluation of the results was carried out according to the NCCLS criteria $(4,14,17,21)$ differentiating the bacteria as sensitive, moderately susceptible, and resistant strains. Because of the explicitness of the results obtained, no statistical calculations were performed.

\section{Results}

The bacteriological examination showed that in all analysed dairy barns infectious and environmental bacteria were isolated. In the group of contagious bacteria, the presence of typical pathogens responsible for the mammary gland infections, i.e. Staph. aureus, Str. agalactiae, and C. bovis, was detected (5, 6, 8-11, $13,16,19,22)$. A relatively broad group of isolates was formed by environmental bacteria responsible for mastitis: Str. dysgalactiae, Str. uberis, Staph. chromogenes, Staph. hyicus, Staph. warneri, and E. coli. A detailed list of the isolates is presented in Tables 1 and 2 .

Table 1. Bacteria isolated from cows with mastitis

\begin{tabular}{lc}
\hline Mastitis-causing bacteria & Number of isolated bacteria \\
\hline Str. uberis & 5 \\
\hline Str. agalactiae & 27 \\
\hline Streptococcus spp. & 5 \\
\hline Str. dysgalactiae & 11 \\
\hline C. bovis & 4 \\
\hline Staph. aureus & 19 \\
\hline Staph. hyicus & 3 \\
\hline Staph. haemolyticus & 9 \\
\hline E. coli & 8 \\
\hline
\end{tabular}

Among the environmental organisms, streptococci accounted for the largest percentage $(23 \%)$, followed by staphylococci $(13.2 \%)$, and E. coli $(8.8 \%)$. The largest group of infectious pathogens comprised Str. agalactiae (29.6\%) and Staph. aureus (20.8\%). At the same time, it cannot be inferred whether the number of cows in the farm can influence the type and quantity of the isolated pathogens (Table 3).

As shown in Table 4, the tested isolates exhibited different levels of resistance to cefalosporins. C. bovis isolates showed $100 \%$ resistance to cefalothin, similarly as $E$. coli to cefazolin. Then, in successive order, $80 \%$ of the tested strains of $C$. bovis were resistant to cefacetrile and $60 \%$ of the isolates were resistant to cefoperazone. The susceptibility of the tested pathogens to cefalosporins was generally low. 
Table 2. Number of contagious and environmental microorganisms isolated in each farm

\begin{tabular}{lllllllllllllll}
\hline $\begin{array}{l}\text { Farm } \\
(\mathrm{n}=12)\end{array}$ & 1 & 2 & 3 & 4 & 5 & 6 & 7 & 8 & 9 & 10 & 11 & 12 & Total & $\%$ \\
\hline $\begin{array}{l}\text { Contagious } \\
\text { microorganisms }\end{array}$ & 4 & 2 & 3 & 5 & 1 & 4 & 2 & 3 & 6 & 1 & 1 & 2 & 34 & 37.3 \\
\hline $\begin{array}{l}\text { Environmental } \\
\text { microorganisms }\end{array}$ & 4 & 5 & 3 & 3 & 6 & 5 & 7 & 3 & 3 & 7 & 6 & 5 & 57 & 62.7 \\
\hline
\end{tabular}

S-small farm, L-large farm

Table 3. The amount of isolated microorganisms depending on the number of dairy cows on the farm

\begin{tabular}{lll}
\hline Isolated microorganisms & $\begin{array}{l}\text { The number of } \\
\text { cows below 20 }\end{array}$ & $\begin{array}{l}\text { The number of } \\
\text { cows above 50 }\end{array}$ \\
\hline Str. uberis & 4 & 1 \\
\hline Str. agalactiae & 11 & 16 \\
\hline Streptococcus spp. & 5 & 0 \\
\hline Str. dysgalactiae & 9 & 2 \\
\hline C. bovis & 4 & 0 \\
\hline Staph. aureus & 9 & 10 \\
\hline E. coli & 5 & 3 \\
\hline Staph. hyicus & 2 & 1 \\
\hline Staph. haemolyticus & 5 & 4 \\
\hline Envinronmental $(\%)$ & 44.5 & 30 \\
Contagious $(\%)$ & 55.5 & 70 \\
\hline
\end{tabular}

Table 4. Sensitivity of isolated mastitis-causing bacteria to selected $\beta$-lactam antibiotics

\begin{tabular}{|c|c|c|c|c|c|c|c|}
\hline Pathogens & $\begin{array}{l}\text { Staph. Aureus } \\
\%\end{array}$ & $\begin{array}{l}\text { Str.agalactiae } \\
\%\end{array}$ & $\begin{array}{l}\text { C. bovis } \\
\%\end{array}$ & $\begin{array}{l}\text { Str. dysgalactiae. } \\
\%\end{array}$ & $\begin{array}{l}\text { Str. Uberis } \\
\%\end{array}$ & $\begin{array}{l}\text { E.coli } \\
\%\end{array}$ & $\begin{array}{l}\text { Staph. haemolyticus } \\
\%\end{array}$ \\
\hline \multicolumn{8}{|l|}{ Antibiotic } \\
\hline \multirow{3}{*}{ benzylpenicillin G } & S - 20 & S- 80 & S- 100 & S- 80 & S-20 & S-ne & $\mathrm{S}-40$ \\
\hline & AS- 0 & AS-20 & AS- 0 & AS- 20 & AS- 80 & AS-ne & AS-0 \\
\hline & $\mathrm{R}-80$ & $R-0$ & R- 0 & R- 0 & $\mathrm{R}-0$ & R-ne & R-60 \\
\hline \multirow{3}{*}{ cloxacillin } & S - 60 & S- 40 & S- 0 & S- 0 & $\mathrm{~S}-0$ & S-ne & S-40 \\
\hline & AS-20 & AS- 0 & AS- 100 & AS- 20 & AS-20 & AS-ne & AS-0 \\
\hline & $R-20$ & R- 60 & R- 0 & R- 80 & $\mathrm{R}-80$ & R-ne & R-60 \\
\hline \multirow{3}{*}{ ampicillin } & S - 60 & S- ne & S- 100 & S- ne & $\mathrm{S}-80$ & S-0 & S-0 \\
\hline & AS- 0 & AS- ne & AS- 0 & AS-ne & AS-20 & AS-60 & AS-20 \\
\hline & $\mathrm{R}-40$ & R-ne & $\mathrm{R}-0$ & R-ne & $\mathrm{R}-0$ & $\mathrm{R}-40$ & $\mathrm{R}-80$ \\
\hline \multirow{3}{*}{ amoxycillin } & S - 80 & S- 0 & S- 0 & S-20 & S-20 & S-60 & S-20 \\
\hline & AS- 20 & AS- 100 & AS- 100 & AS- 80 & AS- 80 & AS-40 & AS-60 \\
\hline & $R-0$ & R- 0 & R- 0 & $\mathrm{R}-0$ & $\mathrm{R}-0$ & $\mathrm{R}-0$ & $\mathrm{R}-20$ \\
\hline \multirow{3}{*}{ cefacetril } & $\mathrm{S}-0$ & S- 0 & S- 0 & S-30 & S-20 & S-0 & S-50 \\
\hline & AS- 100 & AS- 100 & AS-20 & AS-50 & AS- 80 & AS-60 & AS-0 \\
\hline & $\mathrm{R}-0$ & R- 0 & $\mathrm{R}-80$ & $\mathrm{R}-20$ & $\mathrm{R}-0$ & $\mathrm{R}-40$ & $\mathrm{R}-50$ \\
\hline \multirow{3}{*}{ cefazolin } & $\mathrm{S}-0$ & S- 50 & S-ne & S-80 & S-ne & S-0 & S-20 \\
\hline & AS- 80 & AS- 50 & AS- ne & AS-20 & AS-ne & AS-0 & AS-40 \\
\hline & $\mathrm{R}-20$ & $\mathrm{R}-0$ & R- ne & $\mathrm{R}-0$ & R-ne & $\mathrm{R}-100$ & $\mathrm{R}-40$ \\
\hline \multirow{3}{*}{ cefalothin } & $\mathrm{S}-0$ & S- ne & S-0 & S-ne & S-ne & S-ne & S-ne \\
\hline & AS- 80 & AS- ne & AS0 & AS-ne & AS-ne & AS-ne & AS-ne \\
\hline & $\mathrm{R}-20$ & R- ne & $\mathrm{R}-100$ & R-ne & R-ne & R-ne & R-ne \\
\hline \multirow{3}{*}{ cefoperazone } & S - 20 & S- 35 & S-40 & S-20 & S-ne & S-ne & S-20 \\
\hline & AS- 89 & AS- 35 & AS-0 & AS-80 & AS-ne & AS-ne & AS-20 \\
\hline & $R-0$ & R- 30 & $\mathrm{R}-60$ & $\mathrm{R}-0$ & R-ne & R-ne & $\mathrm{R}-60$ \\
\hline
\end{tabular}

$\mathrm{S}$ - sensitive, AS - moderately sensitive, $\mathrm{R}$ - resistant, ne - not examined

The highest percentage ( $80 \%$ ) of Str. dysgalactiae isolates was susceptible to cefazolin, while $50 \%$ of Str. agalactiae strains were sensitive to it. Staph. haemolyticus strains showed the same sensitivity to cefacetrile. The sensitivity of all other isolates to four tested cefalosporins ranged between $20 \%$ and $35 \%$ (Table 4). Resistance to benzylpenicillin $\mathrm{G}$ ranged from $80 \%$ (Staph. aureus) to $60 \%$ (Staph. haemolyticus). 
A relatively high sensitivity to benzylpenicillin $\mathrm{G}$ in the range of $80-100 \%$ was noted in Str. agalactiae and C. bovis. A high percentage of the tested isolates was resistant to cloxacillin: Str. agalactiae - 60\%, Staph. haemolyticus - 60\%, and Str dysgalactiae - 80\%. While estimating the results for aminopenicillins, it was assumed that the resistance to ampicillin in the case of E. coli and Staph. haemolyticus strains was higher in comparison to amoxycillin, while the highest percentage of the strains sensitive to both aminopenicillins was found in the case of Staph. aureus and Str. uberis (Table 4).

\section{Discussion}

The average percentage of cows with mastitis caused by infectious bacteria was 37.3 and mastitis caused by environmental organisms accounted for 62.7 of the analysed cases. A variation between the farms in the occurrence of contagious and environmental bacteria among the examined isolates was observed. For example, in farms 4 (small farm) and 9 (large farm), the dominant pathogens responsible for mastitis were infectious bacteria (Staph. aureus and Str. agalactiae). However, in farms 5 (large farm), 7 (small farm), 10 (large farm), and 11 (large farm), environmental bacteria dominated. In other farms, both infectious and environmental microorganisms were isolated in similar quantities. While analysing the diversity in the occurrence of pathogens responsible for mastitis in particular farms, no rules can be deduced from the distribution of contagious and environmental microorganisms. It should be stressed that in the analysed regions of our country, the environmental bacteria were the aetiological factors of mastitis in a large percentage of cases.

In a study conducted in 2001-2006 (24), it was reported that the average percentage of staphylococcal isolates resistant to benzylpenicillin $\mathrm{G}$ was relatively low $(28.9 \%)$, especially in comparison to the resistance of these pathogens $(60 \%-80 \%)$ isolated in the examined farms. A higher level of resistance of staphylococci (55.5\% Staph. aureus and coagulase-negative - 49.4\%) was noted by other authors in the national research (14). The existing data confirm that staphylococci resistant to penicillin $\mathrm{G}$ and cloxacillin are still a major problem in the treatment of mastitis. According to many authors $(14,23,24)$ as well as our data, the high resistance to ampicillin in staphylococci and E. coli strains should be a prerequisite for not using this antibiotic in cases of mastitis without verifying its effectiveness in vitro. Moreover, during the treatment of so-called acute cases of mastitis, ampicillin should not be the medicine of choice when it is necessary to introduce an antibiotic at random. The relatively high percentage of cephalosporin-resistant isolates among all the evaluated microorganisms against the tested cefalosporins prompts more prudent use if the susceptibility of aetiological factor has not been determined.

Assessment of sensitivity of mastitis isolates to antibiotics allows for proper selection of medicines, reduces the probability of lack of treatment efficiency, and contributes to decreasing the scale of antibiotics use. The in vitro tests of the isolated bacteria's sensitivity to chemotherapeutics also provide early assessment of the scale of increase of resistant strains in farms or in medical practice. The results of the bacteriological examinations presented here confirm the need for continuous monitoring of the sensitivity to antibiotics of both contagious and environmental microorganisms.

In conclusion, our investigation of the current profile of the isolates responsible for mastitis in the Lublin and Bialystok Provinces showed that environmental bacteria are the major cause of the disease. It was also shown that Streptococci were the predominant pathogen in this group of microorganisms. The results concerning the resistance of the analysed pathogens to $\beta$-lactam antibiotics showed a different level of their sensitivity to these chemotherapeutics. For example, $100 \%$ resistance was detected in the C. bovis strains to cefalothin and up to $80 \%$ susceptibility of Str. dysgalactiae to cefazolin was found. A particularly high proportion of resistance in all isolates tested was recorded in the case of cloxacillin. In the group of aminopenicillins, there was a higher resistance of E. coli and Staph. haemolitycus strains to ampicillin compared to amoxicillin. In view of the substantially varying degrees of sensitivity of microorganisms isolated from cases of mastitis to $\beta$-lactam antibiotics, each therapeutic treatment should be preceded by susceptibility testing.

Conflict of Interests Statement: The Authors declare that there is no conflict of interests regarding the publication of this article.

Financial Disclosure Statement: This work was financially supported by the Polish Ministry of Science and Higher Education (Project No. N N308 603 438).

Animal Rights Statement: We declare that the experiments on animals were conducted in accordance with local Ethical Committee laws and regulations as regards care and use of laboratory animals.

\section{References}

1. Bradley A.J.: Bovine mastitis: an evolving disease. Vet J 2002, $163,1-13$.

2. Costa E.O., Ribeiro A.R., Watanabe E.T., Melville P.A.: Infectious bovine mastitis caused by environmental organisms. J Vet Med B 1998, 45, 65-71.

3. Eenennaam A.L., Van Gardner A.L., Holmes J., Perani L., Anderson R.J., Cullor J.S., Guterbock W.W.: Financial analysis of alternative treatments for clinical mastitis associated with environmental pathogens. J Dairy Sci 1995, 78, 2086-2090. 
4. Gruet P., Maincent P., Berthelot X., Kaltsatos V.: Bovine mastitis and intramammary drug delivery: review and perspectives. Adv Drug Deliver Rev 2001, 50, 245-259.

5. Guérin-Faublée V., Carret G., Houffschmitt P.: In vitro activity of 10 antimicrobial agents against bacteria isolated from cows with clinical mastitis. Vet Rec 2003, 152, 466-471.

6. Heringstad B., Klemetsdal G., Ruane J.: Selection for mastitis resistance in dairy cattle: a review with focus on the situation in the Nordic countries. Livest Prod Sci 2000, 64, 95-106.

7. Hornish R.E., Katarski S.F.: Cephalosporins in veterinary medicine. Ceftiofur use in food animals. Curr Top Med Chem 2002, 2, 717-720.

8. Kłosowska A., Malinowski E., Kuźma K.: Relationship between somatic cell counts in cow quarter foremilk samples and etiological agents of mastitis. Med Weter 2005, 61, 53-57.

9. Krukowski H.: Intramammary infections caused by environmental pathogens in cows. Med Weter 2006, 62, 189-192.

10. Kurek C., Niemczuk K.: Patterns of phages of staphylococci isolated from udders of cows and their antibiotic resistance. Med Weter 1987, 43, 270-273.

11. Lassa H., Kubiak J., Małkińska-Horodyska M.: Antibiotic susceptibility of the bacteria most often isolated from clinical mastitis in cows. Życie Wet 2013, 88, 651-653.

12. Malinowski E., Kłosowska A., Kuźma K., Krakowski H.: Antibiotic sensitivity of bacteriae isolated from bovine mastitis. Med Weter 1992, 48, 366-400.

13. Malinowski E., Kłosowska A., Lassa H.: Variability among etiological agents of clinical mastitis in cows. Pol J Vet Sci 2001, 4, 41-45.

14. Malinowski M., Kłosowska A.: Cow mastitis pathogen resistance to antibiotics. Med Weter 2003, 59, 230-235.

15. Malinowski M. Kłosowska A.: Diagnostyka zakażeń i zapaleń gruczołu mlekowego krów. PIWet, Puławy, 2002.

16. Muhammad G., Hoblet K., Jackwood D., Bech-Nielsen S., Smith K.: Interspecific conjugal transfer of antibiotic resistance among staphylococci isolated from the bovine mammary gland. Am J Vet Res 1993, 54, 1432-1440.

17. NCCLS, (1987-1998) Performance Standards for Antimicrobial Susceptibility Testing. Eleventh Informational Supplement, NCCLS document M 100-911 (ISBN 1-56238-426-0). NCCLS, 2001, Pennsylvania, USA.

18. Quinn, P.J., Carter, M.E., Markey, B., Carter, G.R.: Corynebacterium species and Rhodococcus equi. In: Clinical Veterinary Microbiology. Wolf Publishing, London 1994, pp. 327-344.

19. Rabello R.F., Souza C.R.V.M., Duarte R.S., Lopes R.M.M., Teixeira L.M., Castro A.C.D.: Characterization of Staphylococcus aureus isolates recovered from bovine mastitis in Rio de Janeiro, Brazil. J Dairy Sci 2005, 88, 3211-3219.

20. Rossitto P.V., Ruiz L., Kikuchi Y., Glenn K., Luiz K., Watts J.L., Cullor J.S.: Antibiotic susceptibility patterns for environmental streptococci isolated from mastitis in central California dairies. J Dairy Sci 2002, 85, 132-138.

21. Saran A., Leitner G.: Interactions between bacteria, immunity and therapy in mammary gland. Proc. INF Inter. Symp. Immunology of ruminant mammary gland, Stresa, Italy, 2000.

22. Watts J.L. Salmon J.A.: Activity of selected antimicrobial agents against strains of Staphylococcus aureus isolated from bovine intramammary infections that produce beta-lactamase. J Dairy Sci 1997, 80, 788-791.

23. Wawron W., Piech T., Bochniarz M.: Antibiotic sensitivity of pathogens isolated from cows with mastitis. Med Weter 2008, 64, 1132-1135.

24. Wawron W., Szczubiał M., Piech., Krzyżanowski J., Wrona Z., Krakowski L.: Antibiotic-sensitivity of bacteria isolated from cases of bovine mastitis. Med Weter 2000, 56, 675-680.

25. Weller J.L., Saran A., Zeliger Y.: Genetic and environmental relationships among somatic cell count, bacterial infection, and clinical mastitis. J Dairy Sci 1992, 75, 2532-2540. 